\title{
GAMBARAN PENANGANAN PERTAMA KEJANG DEMAM YANG DILAKUKAN IBU PADA BALITA
}

\author{
Hutri Engla Resti ${ }^{1}$, Ganis Indriati ${ }^{2}$, Arneliwati ${ }^{3}$ \\ ${ }^{1,2,3}$ Fakultas Keperawatan Universitas Riau \\ Fakultas Keperawatan Universitas Riau Jalan Pattimura No 9 \\ Gedung G Pekanbaru Riau Kode Pos 28131 Indonesia \\ Email: englaresti01@gmail.com
}

\begin{abstract}
Abstrak
Kejang demam adalah bangkitan kejang yang terjadi pada kenaikan suhu tubuh yang disebabkan oleh proses ekstrakranium. Penelitian ini bertujuan untuk mengetahui gambaran penanganan pertama kejang demam yang dilakukan ibu pada balita di wilayah Puskesmas Rawat Inap Tenayan Raya dan Simpang Tiga, kota Pekanbaru. Desain penelitian yang digunakan adalah deskriptif dengan pendekatan retrospektif. Penelitian ini dilakukan pada 52 orang ibu sebagai sampel yang diambil dari teknik non probability sampling dengan jenis total sampling. Alat ukur yang digunakan adalah lembar kuesioner yang telah dilakukan uji validitas dan uji reliabilitas. Analisa data yang digunakan dalam penelitian ini adalah deskriptif. Hasil penelitian menemukan bahwa sebagian responden telah melakukan penanganan pertama kejang demam yang terdiri dari bersikap tetap tenang dan tidak panik $(90,4 \%)$, tidak melonggarkan pakaian anak $(86,5 \%)$, memiringkan kepala anak $(69,2 \%)$, memasukkan sesuatu kedalam mulut anak $(75,0 \%)$, tidak mengukur suhu tubuh anak $(84,6 \%)$, tidak mencatat lama kejang $(92,3 \%)$, menyingkirkan benda tajam $(71,2 \%)$, tidak memberikan diazepam rektal $(82,7 \%)$ dan membawa anak ke dokter atau puskesmas $(100 \%)$. Hasil penelitian ini merekomendasikan agar tenaga kesehatan khususnya perawat dapat meningkatkan promosi kesehatan tentang penanganan pertama kejang demam dengan cara memberikan pendidikan kesehatan atau memberikan leaflet.
\end{abstract}

Kata kunci: balita, kejang demam, penanganan pertama

\begin{abstract}
Fever seizures are a resurgence of seizures that occur at the increase of body temperature that caused by an extracranium process. This study aims to description the first handling of fever seizures performed on children in the work area of the Tenayan Raya and Simpang Tiga Public Health Center in Pekanbaru. The research design was descriptive with a retrospective approach. This research was conducted on 52 samples using non probability sampling technique with of total sampling type. The measuring instrument used was questionnaire that have been tested for validity and reliability. Analysis of the data used descriptive. The results found description of the first handling of fever seizure by mother were keep calm and not panic (90.4\%), not loosen the children's clothing (86.5\%), tilt the child's head (69.2\%), do put anything in the mouth of the child (75.0\%), not measure body temperature (84.6\%), not record the duration of the seizures (92.3\%), put away sharp objects (71.2\% ), not give rectal diazepam (82.7\%) and bring children to the doctor or public health center (100.0\%). This research is recommended for nurse at Public Health Center to increase knowledge of mother about first handling of fever seizure by providing health education or giving leaflets.
\end{abstract}

Keyword: children, fever seizures, first handling

\section{PENDAHULUAN}

Kejang demam merupakan salah satu gangguan neurologik yang paling sering dijumpai pada masa anak-anak, terutama pada usia 6 bulan sampai 5 tahun (Wong, 2009). Kejang demam adalah serangan kejang yang terjadi karena kenaikan suhu tubuh (suhu rektal diatas $38^{\circ} \mathrm{C}$ ). Kejang 
Hutri Engla Resti ${ }^{1}$, Ganis Indriati ${ }^{2}$, Arneliwati ${ }^{3}$, Gambaran Penanganan Pertama Kejang Demam yang Dilakukan Ibu pada Balita

terjadi apabila demam disebabkan oleh infeksi yang mengenai jaringan ekstrakranial seperti tonsilitis, otitis media akut dan brokitis. Selain demam yang tinggi, kejang juga bisa terjadi akibat penyakit radang selaput otak, tumor, trauma atau benjolan dikepala serta gangguan elektrolit dalam tubuh (Riyadi \& Sukarmin, 2013).

Angka kejadian kejang demam di Amerika Serikat dan Eropa Barat pada tahun 2007 berkisar antara 4-5\% (Brough, 2008). Angka kejadian kejang demam di Asia dilaporkan lebih tinggi, sekitar 8,3-9,9\%. Angka kejadian kejang demam di Indonesia pada tahun 2012-2013 berjumlah 3-4\% pada anak yang berusia 6 bulan-5 tahun (Wibisono, 2015).

Kejang demam merupakan kondisi kegawatdaruratan yang memerlukan penanganan pertama, diikuti kondisi kegawatdaruratan lain yang terjadi pada anak adalah sesak nafas, kenaikan suhu yang terus menerus, dan cedera fisik. Kebanyakan ibu tidak menyadari akan bahaya yang ditimbulkan dari kejang demam. Setiap kejang yang lama (lebih dari 5 menit) berdampak membahayakan karena dapat menyebabkan kerusakan sel-sel otak akibat kekurangan oksigen, semakin lama dan semakin sering kejang maka sel-sel otak yang rusak akan semakin banyak (Chomaria, 2015). Kejang demam juga bisa meningkatkan resiko terjadinya epilepsi sebesar $57 \%$ jika terjadi berulang dan berkepanjangan. Keterlambatan dan kesalahan dalam penanganan pertama kejang demam juga dapat meningkatkan gejala sisa pada anak dan bisa menyebabkan kematian (Fida \& Maya, 2012).

Kejang demam hal yang menakutkan bagi sebagian besar orang tua khususnya ibu. Seorang ibu akan merasa khawatir dan panik jika melihat anaknya mendadak mengalami kejang demam. Seringkali ibu tidak tahu harus berbuat apa saat anak mengalami kejang demam. Oleh karena itu, kejang demam yang terjadi pada anak akan berdampak pada psikologis orang tua terutama ibu, dimana kebanyakan ibu mengalami ansietas (kecemasan berlebihan), depresi, merasa bersalah, ketakutan akan berulangnya kejang (Tarigan, 2007).

Dampak yang ditimbulkan kejang demam cukup berbahaya bagi anak, sehingga perlunya dilakukan penanganan pertama kejang demam. Penanganan pertama kejang demam pada anak sangat tergantung pada peran orang tua, terutama pada ibu. Penanganan pertama kejang demam yang dilakukan ibu diharapkan dapat meminimalisir dampak yang ditimbulkan pada anak.

Peneliti melakukan studi pendahuluan pada tanggal 15 Mei 2019 diwilayah Puskesmas Tenayan Raya Pekanbaru, dengan cara wawancara 6 orang ibu yang anaknya pernah mengalami kejang demam. Hasil wawancara didapatkan 4 dari 6 ibu 
mengatakan panik saat melihat anak kejang demam dan melakukan penanganan pertama saat melihat anak mengalami kejang demam. Penanganan yang dilakukan diantaranya memasukkan sendok kedalam mulut anak, memberikan kopi, dan memberikan kompres hangat pada anak, sedangkan 2 orang ibu lainnya melonggarkan pakaian anaknya dan memberikan kompres air hangat dan setelah kejang berhenti membawa anak ke dokter atau rumah sakit terdekat.

Tujuan penelitian ini adalah untuk mengetahui gambaran penanganan pertama kejang demam yang dilakukan ibu pada balita.

Penelitian ini diharapkan dapat menjadi sumber informasi dan sebagai tambahan informasi bagi ilmu keperawatan tentang gambaran penanganan pertama kejang demam yang dilakukan ibu pada balita.

\section{METODE PENELITIAN}

Desain pada penelitian ini adalah penelitian deskriptif dengan menggunakan pendekatan retrospektif. Populasi pada penelitian ini adalah seluruh ibu yang mempunyai balita yang pernah mengalami kejang demam sebanyak 52 balita di wilayah kerja Puskesmas Rawat Inap dengan kunjungan tertinggi sekota Pekanbaru yaitu Tenayan Raya dan Simpang Tiga Kota Pekanbaru.

Sampel pada penelitian ini adalah seluruh ibu yang mempunyai balita yang pernah mengalami kejang demam yang diambil dengan teknik total sampling dengan jumlah sampel sebanyak 52 orang. Alat pengumpulan data dalam penelitian adalah kuisioner mengenai data demografi pasien dan kuesioner untuk mengidentifikasi penanganan pertama kejang demam yang dilakukan ibu pada balita. Kuesioner ini terdiri dari 11 item pernyataan yang dari 8 pernyataan positif $(2,3,4,7,8,9,10,11)$ dan 3 pernyataan negatif $(1,5,6)$ dimana responden yang menjawab benar diberi nilai 1 sedangkan jawaban salah diberi nilai 0 menggunakan skala Guttman.

Analisis data yang digunakan yaitu analisa deskriptif dan hasilnya ditampilkan dengan distribusi frekuensi dan persentase dari karakteristik responden (usia ibu, usia anak, jumlah anak, jenis kelamin anak, pekerjaan, pendidikan terakhir) dan variabel penelitian (penanganan pertama yang dilakukan ibu pada balita).

\section{HASIL PENELITIAN}

Penelitian telah dilakukan selama 9 hari hasilnya adalah sebagai berikut:

\section{Karakteristik Responden}

Tabel 1

Distribusi frekuensi karakteristik responden dan anaknya

\begin{tabular}{lcc}
\hline $\begin{array}{l}\text { Karakteristik } \\
\text { Responden }\end{array}$ & $\begin{array}{c}\text { Frekuensi } \\
(\mathbf{n})\end{array}$ & $\begin{array}{c}\text { Persentasi } \\
(\boldsymbol{\%})\end{array}$ \\
\hline Usia ibu & & \\
20-35 tahun & 47 & 90,4 \\
26-40 tahun & 5 & 9,6 \\
\hline Usia anak & & \\
0-12 bulan & 51 & 98,1 \\
13-36 bulan & 1 & 1,9
\end{tabular}


Hutri Engla Resti ${ }^{1}$, Ganis Indriati ${ }^{2}$, Arneliwati $^{3}$, Gambaran Penanganan Pertama Kejang Demam yang Dilakukan Ibu pada Balita

\begin{tabular}{lcc}
\hline $\begin{array}{l}\text { Karakteristik } \\
\text { Responden }\end{array}$ & $\begin{array}{c}\text { Frekuensi } \\
(\mathbf{n})\end{array}$ & $\begin{array}{c}\text { Persentasi } \\
(\boldsymbol{\%})\end{array}$ \\
\hline 37-60 bulan & 0 & 0 \\
\hline Jumlah anak & & \\
Anak ke 1 & 26 & 50,0 \\
Anak ke 2 & 16 & 30,8 \\
Anak ke 3 & 10 & 19,2 \\
\hline Jenis Kelamin Anak & & \\
Laki-laki & 35 & 67,3 \\
Perempuan & 17 & 32,7 \\
\hline Pekerjaan & & \\
PNS & 9 & 17,3 \\
Wiraswasta & 1 & 1,9 \\
KaryawanSwasta & 1 & 1,9 \\
Ibu rumah tangga (IRT) & 41 & 78,8 \\
Lain-lain & 0 & 0 \\
\hline Pendidikan & & \\
Tidak sekolah & 0 & 0 \\
SD & 0 & 0 \\
SMP & 1 & 1,9 \\
SMA & 28 & 53,8 \\
D3/S1 & 23 & 44,2 \\
S2 & 0 & 0 \\
\hline Total & 52 & 100,0 \\
\hline
\end{tabular}

\begin{tabular}{lcc}
\hline Tidak melakukan & 5 & 9,6 \\
\hline Melakukan & 47 & 90,4 \\
\hline Total & 52 & 100,0 \\
\hline
\end{tabular}

Tabel 2, menunjukkan bahwa mayoritas responden tetap tenang dan tidak panik dalam melakukan penanganan pertama yaitu sebanyak 47 responden $(90,4 \%)$.

Tabel 3

Distribusi frekuensi melonggarkan pakaian anak

\begin{tabular}{lcc}
\hline $\begin{array}{l}\text { Melonggarkan } \\
\text { pakaian anak }\end{array}$ & Frekuensi & Persentase \\
\hline Tidak Melakukan & 45 & 86,5 \\
\hline Melakukan & 7 & 13,5 \\
\hline Total & 52 & 100,0 \\
\hline
\end{tabular}

Tabel 3, menunjukkan bahwa mayoritas

Tabel 1 menunjukkan mayoritas usia responden 20-35 tahun sebanyak 47 responden (90,4\%). Mayoritas anak responden berusia $0-12$ bulan sebanyak 51 anak $(98,1 \%)$. Responden rata-rata memiliki anak pertama yaitu 26 responden (50\%). Jenis kelamin anak responden sebagian besar laki-laki sebanyak $35 \quad(67,3 \%)$ dengan pekerjaan mayoritas ibu rumah tangga sebanyak 41 responden $(78,8 \%)$ dan pendidikan terakhir responden sebagian besar adalah SMA sebanyak 28 responden $(53,8 \%)$.

\section{Gambaran penanganan pertama kejang} demam yang dilakukan ibu pada balita

\section{diuraikan pada tabel berikut.}

Tabel 2

Distribusi frekuensi tetap tenang dan tidak panik

\begin{tabular}{lll}
\hline Tetap tenang dan & Frekuensi & Persentase \\
jangan panik & \\
\hline
\end{tabular}

Tabel 5

Distribusi frekuensi tidak memasukkan sesuatu kedalam mulut anak

\begin{tabular}{lcc}
\hline $\begin{array}{l}\text { Tidak memasukkan } \\
\text { sesuatu kedalam } \\
\text { mulut anak }\end{array}$ & Frekuensi & Persentase \\
\hline Tidak Melakukan & 13 & 25,0 \\
\hline Melakukan & 39 & 75,0 \\
\hline Total & 52 & 100,0 \\
\hline
\end{tabular}

Distribusi memiringkan kepala anak

\begin{tabular}{lcc}
\hline $\begin{array}{l}\text { Memiringkan } \\
\text { kepala anak }\end{array}$ & Frekuensi & Persentase \\
\hline Tidak Melakukan & 16 & 30,8 \\
\hline Melakukan & 36 & 69,2 \\
\hline Total & 52 & 100,0 \\
\hline
\end{tabular}

Tabel 4, diketahui bahwa sebagian besar responden memiringkan kepala anak yaitu sebanyak 36 responden $(69,2 \%)$. 
Tabel 5, diketahui sebagian besar responden memasukkan sesuatu kedalam mulut anak sebanyak 39 responden $(75,0 \%)$.

Tabel 6

Distribusi frekuensi mengukur suhu tubuh anak

\begin{tabular}{lcc}
\hline $\begin{array}{l}\text { Mengukur suhu, } \\
\text { tubuh anak }\end{array}$ & Frekuensi & Persentase \\
\hline Tidak Melakukan & 44 & 84,6 \\
\hline Melakukan & 8 & 15,4 \\
\hline Total & 52 & 100,0 \\
\hline
\end{tabular}

Tabel 6, diketahui sebagian besar responden tidak mengukur suhu tubuh anak sebanyak 44 responden $(84,6 \%)$.

Tabel 7

Distribusi frekuensi mencatat lama kejang

\begin{tabular}{lcc}
\hline Mencatat lama kejang & Frekuensi & Persentase \\
\hline Tidak Melakukan & 48 & 92,3 \\
\hline Melakukan & 4 & 7,7 \\
\hline Total & 52 & 100,0 \\
\hline
\end{tabular}

Tabel 7, diketahui sebagian besar responden tidak mencatat lama kejang yang terjadi pada anak sebanyak 48 responden $(92,3 \%)$.

Tabel 8

Distribusi frekuensi menyingkirkan benda tajam

\begin{tabular}{lcc}
\hline $\begin{array}{l}\text { Menyingkirkan } \\
\text { benda tajam }\end{array}$ & Frekuensi & Persentase \\
\hline Tidak Melakukan & 15 & 28,8 \\
\hline Melakukan & 37 & 71,2 \\
\hline Total & 52 & 100,0 \\
\hline
\end{tabular}

Tabel 8, diketahui sebagian besar responden responden menyingkirkan benda tajam sebanyak 37 responden $(71,2 \%)$.
Tabel 9

Distribusi frekuensi memberikan diazepam rektal

\begin{tabular}{lcc}
\hline $\begin{array}{l}\text { Memberikan } \\
\text { diazepam rektal }\end{array}$ & Frekuensi & Persentase \\
\hline Tidak Melakukan & 43 & 82,7 \\
\hline Melakukan & 9 & 17,3 \\
\hline Total & 52 & 100,0 \\
\hline
\end{tabular}

Tabel 9, diketahui sebagian besar responden tidak memberikan diazepam rektal sebanyak 43 responden $(82,7 \%)$.

Tabel 10

Distribusi frekuensi membawa anak ke dokter atau puskesmas

\begin{tabular}{lcc}
\hline $\begin{array}{l}\text { Membawa anak ke } \\
\text { dokter atau puskesmas }\end{array}$ & Frekuensi & Persentase \\
\hline Tidak Melakukan & 0 & 0 \\
\hline Melakukan & 52 & 100,0 \\
\hline Total & 52 & 100,0 \\
\hline
\end{tabular}

Tabel 10, diketahui mayoritas responden membawa anak ke dokter atau puskesmas sebanyak 52 responden (100\%).

\section{PEMBAHASAN}

\section{Karakteristik Responden}

\section{a. Usia Ibu}

Hasil penelitian menunjukkan sebagian besar responden berumur 20-35 tahun (dewasa awal) yang berjumlah 47 responden $(90,4 \%)$. Usia dapat mempengaruhi kemampuan seseorang untuk menerima informasi dan pola pikir seseorang terhadap informasi yang diberikan. Usia yang emakin bertambahnya maka kemampuan menerima informasi akan semakin berkembang.

Kemampuan seseorang untuk menerima informasi yang diberikan 
Hutri Engla Resti ${ }^{1}$, Ganis Indriati ${ }^{2}$, Arneliwati ${ }^{3}$, Gambaran Penanganan Pertama Kejang Demam yang Dilakukan Ibu pada Balita

kepadanya berhubungan dengan kemampuan otak dan kesehatan seseorang (Notoatmodjo, 2012). Seorang yang usianya semakin dewasa, maka semakin berpengaruh pada proses bertambahnya atau berkurangnya pengetahuan, perubahan sikap dan penguatan perilaku. Usia sangat berpengaruh terhadap cara berpikir untuk melaksanakan suatu kegiatan atau pekerjaan sehingga mampu menerima suatu informasi kejang demam. Usia orangtua yang masih muda juga memungkinkan untuk mempunyai kemampuan yang baik dalam penanganan kejang demam.

\section{b. Usia Anak}

Hasil penelitian menunjukkan mayoritas responden mempunyai anak berusia 0-12 bulan (bayi) sebanyak 51 responden $(98,1 \%)$. Anak yang mengalami kejang demam dipengaruhi oleh usianya. Anak yang berusia 0-12 bulan saat demam lebih rentan mengalami kejang demam. Hal ini tidak sejalan dengan hasil penelitian Nindela, Dewi dan Ansori (2014) usia anak yang mengalami kejang demam paling banyak berusia 12-24 bulan.

Hal ini tidak sejalan dengan teori bahwa seorang anak yang berusia dibawah 3 tahun masa otak belum matang mempunyai eksitabilitas neuro lebih tinggi dibandingkan yang sudah matang disebut developmental window. Developmental window merupakan masa perkembangan otak fase organisasi yaitu waktu anak berusia 24 bulan, sehingga anak yang dibawah usia 24 bulan mempunyai resiko mengalami kejang demam (IDAI, 2013).

\section{c. Jumlah Anak}

Hasil penelitian diperoleh bahwa sebagian besar responden memiliki anak pertama yang mengalami kejang demam yaitu sebanyak 26 anak (50\%). Kebanyakan responden mempunyai satu anak, dimana anak pertama mengalami kejang demam salah satunya disebabkan karena riwayat keluarga yang pernah mengalami kejang demam. Responden melakukan penanganan kejang demam secara spontan. Responden tidak mengetahui dengan benar penanganan pertama untuk mengatasi kejang demam.

\section{d. Jenis kelamin}

Hasil penelitian diperoleh sebagian besar jenis kelamin anak responden yang mengalami kejang demam adalah laki-laki yaitu 35 anak (67,3\%). Kejang demam lebih banyak terjadi pada anak laki-laki. Hal ini dikarenakan bahwa kematangan otak terjadi lebih dahulu pada anak perempuan dari pada anak laki-laki. Hal ini didukung oleh hasil penelitian Fuadi, Bahtera dan Wijayahadi (2010) sebagian besar anak yang mengalami kejang demam berjenis kelamin laki-laki.

Hal ini sejalan dengan teori dari Wong (2009) yang menyatakan anak laki-laki lebih sering menderita kejang demam dengan insidensi sekitar dua kali lipat lebih sering dibandingkan anak perempuan, dan terdapat peningkatan kerentanan dalam keluarga yang 
menunjukkan kemungkinan adanya predisposisi genetik.

\section{e. Pekerjaan}

Hasil penelitian menunjukkan bahwa mayoritas responden tidak bekerja atau sebagai Ibu Rumah Tangga (IRT) yaitu sebanyak 41 responden $(78,8 \%)$. Ibu yang tidak bekerja mempunyai banyak waktu yang dihabiskan bersama anaknya. Hal ini bisa berpeluang bagi seorang ibu untuk mendapatkan informasi dari berbagai sumber informasi seperti media massa dan dapat meningkatkan pengetahuan tentang penanganan pertama kejang demam yang dilakukan pada anaknya. Hal ini sejalan dengan hasil penelitian Arifuddin (2016) bahwa pekerjaan responden terbanyak yaitu Ibu Rumah Tangga (IRT).

\section{f. Pendidikan}

Hasil penelitian menunjukkan sebagian besar responden yang diteliti berpendidikan SMA sebanyak 28 responden $(53,8 \%)$. Pendidikan merupakan faktor pendukung agar informasi yang diperoleh bisa mempengaruhi pemahaman seseorang. Tingkat pendidikan juga dapat mempengaruhi cara berfikir dan cara pandang orangtua khususnya ibu dalam melakukan penanganan pertama kejang demam. Seorang ibu yang telah menempuh pendidikan menengah atas (SMA) akan memiliki kemampuan yang cukup luas dan dapat mencari informasi tentang penanganan pertama pada kejang demam yang bisa dilakukan. Hal ini sesuai dengan penelitian Indrayati dan Haryanti (2019) yang menunjukkan bahwa pendidikan terakhir responden paling banyak yaitu SMA sebanyak 11 orang (34.4\%).

\section{Gambaran penanganan pertama}

\section{kejang demam yang dilakukan ibu pada balita}

\section{a. Tetap tetang dan tidak panik}

Hasil penelitian menemukan mayoritas responden tetap tenang dan tidak panik yaitu berjumlah 47 responden $(90,4 \%)$. Seorang ibu yang bersikap tenang dan tidak panik lebih bisa melakukan tindakan untuk melakukan penanganan pertama kejang demam. Dalam hal ini ibu harus memahami penanganan pertama yang harus bisa dilakukan, terutama harus bersikap tetap tenang dan tidak panik saat melihat anak kejang demam.

Penelitian ini sejalan dengan teori IDAI (2013) dalam penatalaksanaan mengatasi kejang demam pada anak, penolong harus tenang, usahakan supaya tidak panik, perlu menjaga pikiran tetap jernih.

\section{b. Melonggarkan pakaian anak}

Hasil penelitian menemukan mayoritas responden tidak melonggarkan pakaian anak saat anak mengalami kejang demam yaitu sebanyak 45 responden (86,5\%). Kebanyakan ibu tidak melonggarkan pakaian anak terutama dibagian leher anak, kerena ibu tidak mengetahui bahwa melonggarkan 
Hutri Engla Resti ${ }^{1}$, Ganis Indriati ${ }^{2}$, Arneliwati ${ }^{3}$, Gambaran Penanganan Pertama Kejang Demam yang Dilakukan Ibu pada Balita

pakaian anak bisa meminimalisir anak tercekik dan menghambat pernapasan anak. Hal ini tidak sejalan dengan teori Wong (2009) dimana melonggarkan pakaian anak terutama dileher saat kejang demam untuk melancarkan pernafasan anak dan melancarkan pasokan oksigen kedalam tubuh khususnya otak anak.

\section{c. Memiringkan kepala anak}

Hasil penelitian menemukan sebagian besar responden memiringkan kepala anaknya yaitu sebanyak 36 responden $(69,2 \%)$. Memiringkan kepala saat anak mengalami kejang demam bertujuan untuk meminimalisir anak tersedak ludah atau muntahnya sendiri. Tersedak oleh ludah dan muntah dapat menyebabkan penyumbatan jalan nafas yang akan mengganggu pernafasan anak. Anak yang mangalami kejang demam sejatinya membutuhkan pasokan oksigen yang adekuat untuk sampai ke otak supaya mempertahankan kadar oksigen dalam tubuh.

\section{d. Tidak memasukkan sesuatu kedalam mulut anak.}

Hasil penelitian menemukan sebagian besar responden memasukkan sesuatu ke dalam mulut anak sebanyak 39 responden (75\%). Ibu memasukkan benda seperti kayu, sendok atau kain kedalam mulut anak karena ibu takut lidah anak tergigit. Hal yang sama ditemukan pada penelitian dengan penelitian Fauzia (2012) bahwa sebagian besar responden memasukkan sendok yang dililit kain kedalam mulut anak.

Hasil ini tidak sejalan dengan teori IDAI (2013) bahwa memasukkan benda apapun kedalam mulut anak seperti memasukkan sendok, kayu, jari orangtua atau benda lainnya kedalam mulut anak yang sedang mengalami kejang demam berisiko menyebabkan sumbatan jalan nafas dan dapat menghambat pernafasan anak sehingga anak sulit bernafas dan ini akan membahayakan anak dan memperparah kejang.

\section{e. Mengukur suhu tubuh anak}

Hasil penelitian menemukan sebagian besar responden tidak mengukur suhu anak yaitu sebanyak 44 responden $(84,6 \%)$. Ibu tidak mengukur suhu tubuh karena ibu tidak mengetahui bahwa mengukur suhu merupakan hal yang penting dilakukan saat anak kejang demam dan tidak sedikit pula ibu yang menganggap bahwa mengukur suhu tubuh merupakan hal yang tidak perlu dilakukan. Hal ini sesuai dengan teori IDAI (2013) bahwa mengukur suhu tubuh merupakan hal yang penting dilakukan oleh seorang ibu yang mempunyai anak dengan kejang demam, karena hal ini dapat menjadi informasi untuk dokter, sehingga dokter bisa melakukan observasi menyeluruh dan dapat menentukkan penyebab kejang demam. Penelitian ini juga tidak sejalan dengan penelitian Fauzia (2012) sebagian besar mengukur suhu anak dengan thermometer. 


\section{f. Mencatat lama kejang}

Hasil penelitian yang sebagian besar responden tidak mencatat lama kejang pada anak yaitu 48 responden $(92,3 \%)$. Ibu tidak mencatat karena ibu panik melihat anaknya kejang dan ibu tidak mengetahui bahwa mencatat lama kejang merupakan hal yang perlu dilakukan saat melakukan penanganan pertama kejang demam. Hal ini tidak sejalan dengan hasil Herliana (2014) didapatkan ibu mencatat suhu tubuh anaknya sebanyak 16 responden $(62 \%)$. Hasil penelitian ini juga sejalan dengan teori IDAI (2013) bahwa mencatat lama kejang merupakan hal yang penting dilakukan oleh seorang ibu yang mempunyai anak dengan kejang demam, karena hal ini dapat menjadi pegangan ibu untuk menginformasikan kepada dokter lama kejang yang dialami anaknya, sehingga dokter bisa melakukan observasi menyeluruh dan dapat menentukkan penyebab kejang demam

\section{g. Menyingkirkan benda tajam dari sekeliling anak.}

Hasil penelitian menemukan sebagian besar responden menyingkirkan benda tajam sebanyak 37 responden (71,2\%). Sebagian besar ibu menyingkirkan benda-benda tajam seperti mainan-mainan yang bersudut tajam yang dapat melukai anak apabila berada disekitar anak, dan menjauhkan anak dari sumber listrik.

Hal ini didukung oleh teori Riyadi dan Sukarmin (2013) bahwa saat timbul serangan kejang segera jauhkan anak dari benda-benda yang berbahaya seperti gelas atau pisau untuk mencegah cidera tambahan.

\section{h. Memberikan diazepam rectal}

Hasil penelitian menemukan mayoritas responden tidak memberi- kan diazepam rectal sebagai penanganan pertama yaitu sebanyak 43 responden $(82,7 \%)$. Hal ini sejalan dengan penelitian yang dilakukan Herliana (2014) yang mendapatkan bahwa responden tidak memberikan obat anti kejang sebanyak 14 responden (54\%).

Ibu tidak memberikan diazepam rectal karena ini merupakan pengalaman pertama ibu menghadapi anak kejang demam, sehingga ibu tidak menyiapkan obat kejang. Obat yang biasa ibu siapkan di rumah adalah obat penurun panas, obat flu dan obat masuk angin tidak ada ibu yang menyiapkan obat anti kejang dan untuk obat diazepam rectal sendiri tidak dijual bebas di apotik dan harus dengan resep dokter.

\section{i. Membawa anak ke dokter atau puskesmas.}

Hasil penelitian menemukan mayoritas responden membawa anak ke dokter atau rumah sakit setelah kejang sebanyak 52 responden $(100 \%)$. Tindakan pertama yang dipikirkan ibu saat melihat anak kejang demam adalah segera membawa anak ke dokter, hal ini karena ibu merasa panik dan tidak mengetahui penanganan pertama kejang demam pada anak. Ibu berpikir bahwa kejang demam akan mengancam nyawa anak dan 
Hutri Engla Resti ${ }^{1}$, Ganis Indriati ${ }^{2}$, Arneliwati ${ }^{3}$, Gambaran Penanganan Pertama Kejang Demam yang Dilakukan Ibu pada Balita

satu-satunya jalan untuk mengatasinya dengan membawa anaknya ke dokter.

\section{SIMPULAN}

Hasil penelitian menunjukkan bahwa karakteristik responden, mayoritas berumur 20-35 tahun, mempunyai anak yang berusia 0-12 bulan, sebagian besar anak pertama, berjenis kelamin anak laki-laki, pekerjaan ibu rumah tangga (IRT), pendidikan terakhir SMA. Hasil penanganan pertama yang dilakukan ibu pada balita yang terdiri dari sikap tetap tenang dan tidak panic, tidak melonggarkan pakaian anak, memiringkan kepala anak, memasukkan sesuatu ke dalam mulut anak, tidak mengukur suhu tubuh anak, tidak mencatat lama kejang, meyingkirkan benda tajam dari sekeliling anak, tidak memberikan diazepam rectal, dan membawa anak ke dokter atau rumah sakit.

\section{SARAN}

1. Ilmu keperawatan

Hasil penelitian ini diharapkan dapat dijadikan informasi atau data dasar untuk penelitian lanjutan tentang penanganan pertama kejang demam yang dilakukan ibu pada balita.

2. Masyarakat

Hasil penelitian ini diharapkan menjadi informasi bagi masyarakat terutama ibu agar meningkatkan pengetahuan tentang penanganan pertama kejang demam yang dilakukan ibu pada balita.

\section{Penelitian selanjutnya}

Hasil penelitian ini diharapkan dapat dijadikan sebagai dasar atau informasi untuk melaksanakan penelitian lanjutan mengenai penanganan pertama kejang demam yang dilakukan ibu pada balita.

\section{DAFTAR PUSTAKA}

Arifuddin, A. (2016). Analisis faktor risiko kejadian kejang demam di ruang perawatan anak rsu anutapura palu. Jurnal Kesehatan Tadulako Vol, 2(2), 1-72. Diunduh tanggal 22 Mei 2019 dari http://jurnal.untad.ac.id.

Chomaria, N. (2013). Tumbuh kembang anak usia 0-5 tahun. Surakarta: Cinta.

Fauzia, N. A. Pengetahuan, sikap, dan perilaku ibu mengenai kejang demam di Puskesmas Ciputat Timur 2012. Medika Islamika. Diunduh tanggal 15 Mei 2019 dari http://uinjkt.ac.id.

Fida \& Maya. (2012). Pengantar ilmu kesehatan anak. Jogjakarta: D-Medika. Fuadi, F., Bahtera, T., \& Wijayahadi, N. (2016). Faktor risiko bangkitan kejang demam pada anak. Sari Pediatri,12 (3), 143-150. Diunduh tanggal 06 Januari 2019 dari http://www.saripediatri.org.

Ikatan Dokter Anak Indonesia, (2013). Konsensus penatalaksanaan kejang demam. Jakarta: Badan Penerbit IDAI. 
Indrayati, N., \& Haryanti, D. (2019). Gambaran kemampuan orangtua dalam penanganan pertama kejang demam pada anak usia toddler. Jurnal Ilmiah Permas: Jurnal Ilmiah STIKES Kendal, 9(2), 149-154. Diunduh tanggal 16 Juni 2019 dari jurnal http://jurnal.stikeskendal.ac.id.

Nindela, R., Dewi, M. R., \& Ansori, I. Z. (2014). Karakteristik penderita kejang demam di instalasi rawat inap bagian anak rumah sakit Muhammad Hoesin Palembang. Jurnal kedokteran kesehatan: Publikasi Ilmiah Fakultas Kedokteran Universitas Sriwijaya, 1(1), 41-45. Diunduh tanggal 12 Mei 2019 dari http//ejournal.unsri.ac.id

Notoatmodjo, S. (2012). Metodologi penelitian kesehatan. Jakarta: Rineka Cipta.

Riyadi, S., \& Sukarmin. (2013). Asuhan keperawatan pada anak. Yogyakarta: Graha Ilmu.

Tarigan, T., Chairul, A. H., \& Syamsidah, L. (2007). Pengetahuan, sikap dan perilaku orang tua tentang kejang demam dan pentingnya edukasi oleh dokter. Sari Pediatri, 8 (3), 27-31. Diunduh tanggal 22 Januari 2019 dari http://saripediatri.org.
Wibisono, A. (2015). Asuhan keperawatan pada an. $M$ dengan kejang demam di Ruang Mawar RSUD Banyudono. Jurnal Kesehatan. Diunduh tanggal 11 Februari darihttp://jurnal.ums.ac.id Wong, L., Donna. (2009). Buku ajar keperawatan pediatric Wong, Ed. 6, Vol.2. Jakarta: Buku Kedokteran 